\title{
Indoor thermal comfort in urban courtyard block dwellings in the Netherlands
}

\author{
Mohammad Taleghani ${ }^{* 1}$, Martin Tenpierik ${ }^{1}$, Andy van den Dobbelsteen ${ }^{1}$ \\ ${ }^{1}$ Faculty of Architecture and the Built Environment, Delft University of Technology, Delft, the Netherlands
}

\begin{abstract}
Global warming and elevated temperatures in the Netherlands will increase the energy demand for cooling. Studying passive strategies to cope with the consequences of climate change is inevitable. This paper investigates the thermal performance of courtyard dwellings in the Netherlands. The effects of different orientations and elongations, cool roofs and pavements on indoor thermal comfort are studied through simulations and field measurements. The results show that North-South and East-West orientations provide the least and most comfortable indoor environments. Regarding materials, the use of green on roofs and as courtyard pavement is the most effective heat mitigation strategy. It was observed that the effects of wet cool roofs are much higher than of dry roofs. Cool roofs did not show a specific negative effect (heat loss) as compared to conventional asphalt roofs in winter. Some simulation results were validated through field measurement with a $0.91^{\circ} \mathrm{C}$ root mean square deviation.
\end{abstract}

\section{Keywords}

Courtyard buildings, heat mitigation strategies, cool roofs and pavements, indoor thermal comfort.

\footnotetext{
${ }^{1}$ Corresponding Author: Mohammad Taleghani mohamadtaleghani@gmail.com ; m.taleghani@tudelft.nl. Co-authors contacts:

Martin Tenpierik: m.j.tenpierik@tudelft.nl Andy van den Dobbelsteen: a.a.j.f.vandendobbelsteen@tudelft.nl
} 


\section{Introduction}

Global warming is affecting human thermal comfort [1], and it is estimated that by 2050 , the air temperature in the Netherlands could be up to $2.3^{\circ} \mathrm{C}$ warmer than in the period from 1981 to 2014 [2]. The built environment can intensify or moderate the environment. One of the most commonly used building archetypes in hot climates is the courtyard form. Courtyards provide shading and consequently a cool microclimate within a building block. It may also ease ventilation through the stack effect. The thermal behaviour of courtyard buildings has extensively been studied in hot and arid climates, but rarely in temperate regions such as West Europe. Courtyards exist in the Netherlands; rarely as single family houses, but mainly as urban blocks. With the warmer future climate estimated for the Netherlands, this study tries to make this archetype climate proof. Therefore, this paper explores the effect of different courtyard geometries and orientations on the thermal comfort of dwellers in the Netherlands. Heat mitigation strategies such as greenery or high albedo materials on roofs and within courtyards are investigated through simulations. An experiment on a scale model of a courtyard with different roofs and courtyard pavements is done to support the results of the simulations. At the end, a one-month field measurement in an actual courtyard house in Delft is done as a validation of the simulation program used in this paper.

\subsection{Thermal behaviour of courtyard buildings}

Courtyards have been used mostly in harsh climates in order to provide more shading in hot climates, more ventilation in humid climates and more protection against cold winds in temperate and cold climates. In a comparison between different building forms, Okeil [3] generated Residential Solar Blocks (RSB) based on the courtyard form and showed that it is more energy efficient than slabs and pavilions in the hot and humid climate of UAE.

Ratti, et al. [4], based on the six archetypal forms of Martin and March [5], made three "realistic" block layouts for a hot and arid climate. They concluded that the courtyard configuration led to a more favourable micro-climate because of more favourable environmental variables (surface to volume ratio, shadow density, daylight distribution, and sky view factor) as compared to two different pavilion types.

In the temperate climate of the Netherlands, Taleghani, et al. [6] compared courtyard buildings with different urban layouts (linear and singular blocks with the same floor area). They showed this typology has the least summer discomfort hours. This was because of the lower surface-to-volume ratio of the courtyard, and it's shading on the surrounding buildings.

\subsection{Highly reflective materials and cool roofs}

Dark surfaces used in urban environments and the lack of vegetation increase the ambient air temperature in cities. This phenomenon is called the urban heat island (UHI) which is more sensible in summer [7, 8]. Akbari, et al. [9] in a study on American metropolises showed that peak urban electric demand rises by $2-4 \%$ for each $1^{\circ} \mathrm{C}$ increase in air temperature. This is an indirect effect of dark materials; but, the direct effect is their higher absorption of solar energy. With a low albedo, dark materials reflect less solar radiation 
increasing their surface temperature and as a result increasing the energy use for the cooling of buildings, especially during the peak periods of energy demand.

There is a large body of literature on highly reflective materials and vegetated (green) surfaces studied in the hot climates of the USA [10-13] and southern Europe [14-16]; and recently in colder climates such as in Moscow (Russia) [17, 18], Toronto (Canada) [19, 20], and Gothenburg (Sweden) [21]. Vegetation and highly reflective materials are becoming ever more studied and used; however, there are challenges in the use of green roofs. First, the installation and maintenance costs of these roofs are relatively problematic. Sproul, et al. [22] with an economic perspective on 22 case studies with different roof colours showed that relative to black roofs white roofs provide a 50 -year positive net savings and green roofs a negative net savings. Second, the behaviour of these roofs (known as cool roofs) is not always beneficial in winter. This could be due to the shading effect of vegetation on the roof but also due to the higher thermal conductivity of water in wet green roofs and the evapotranspiration of vegetation [23]. Liu and Minor [24] showed that with a proper drainage and insulation layer this problem could be solved for a cold climate like Toronto (Canada).

Reviewing the literature, what has been less studied is the effect of cool materials on the microclimate of urban courtyards, and also its effect on the indoor comfort of the dwellers. The other missing (and important) research in the literature is the thermal behaviour of cool materials and green roofs in winter (in dry and wet modes). Therefore, in this paper the effect of highly reflective materials and vegetation on the roof and on the ground of the courtyard is investigated; in summer and winter, and in dry and wet modes. This will be done through simulations and actual experiments.

\section{Methodology}

This paper consists of three phases. Phase 1 is done through computer simulation. Phase 2 shows the results of a scale model, and phase 3 is a validation of the simulation model using field measurements in an actual courtyard house.

In phase 1, eighteen courtyard buildings are studied for their indoor thermal comfort in the hottest summer week in a reference year (between $16^{\text {th }}$ and $23^{\text {rd }}$ of June). The development of the weather data file for the reference year is explained by Taleghani, et al. [25].These buildings are modelled in DesignBuilder and the thermal properties of the walls, roofs and windows are described in Table 1. The roofs are conventional bitumen. The facades are brick cavity walls with $10 \mathrm{~cm}$ expanded polystyrene standard (EPS) insulation inside the cavity. The type of windows is Double LoE $(\mathrm{e} 2=.2) \mathrm{Clr} 6 \mathrm{~mm} / 6 \mathrm{~mm}$ Air. The window to wall ratio is $30 \%$. The constant rate for the airtightness is $0.1(\mathrm{ac} / \mathrm{h})$. The width of the buildings surrounding a courtyard is 10 meters. This means that the dimension of the building surrounding the $10 \mathrm{~m}^{\star} 10 \mathrm{~m}$ courtyard is $30 \mathrm{~m}^{\star} 30 \mathrm{~m}$. The houses are naturally ventilated by opened windows if the indoor air temperature has risen to above $22^{\circ} \mathrm{C}$. The models are not equipped with a cooling system since most of Dutch dwellings are in free running mode during summer. 
Table 1: The properties used in the simulations.

\begin{tabular}{|l|l|l|}
\hline & $\begin{array}{l}\text { U-value } \\
\mathrm{W} /\left(\mathrm{m}^{2} \mathrm{~K}\right)\end{array}$ & $\begin{array}{l}\text { Thickness } \\
(\mathrm{m})\end{array}$ \\
\hline Roof & 0.31 & 0.210 \\
\hline Wall & 0.33 & 0.350 \\
\hline Glazing & 2.55 & 0.018 \\
\hline
\end{tabular}

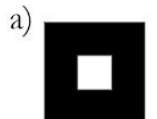

$10 * 10 \mathrm{EW}$

b)

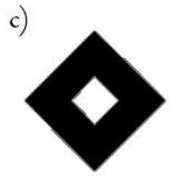

$10 * 10 \mathrm{NE}-\mathrm{SW}$

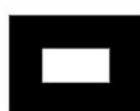

$10 * 20 \mathrm{EW}$

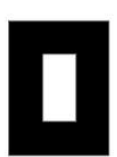

$20 * 10 \mathrm{NS}$

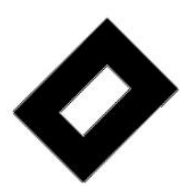

$10 * 20 \mathrm{NE}-\mathrm{SIV}$

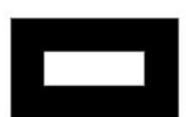

$10 * 30 \mathrm{EW}$

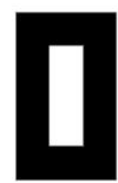

$30 * 10 \mathrm{NS}$

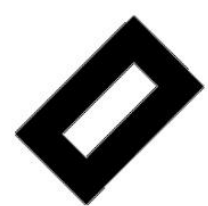

$10 * 30 \mathrm{NE}-\mathrm{SW}$

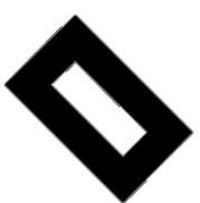

$30 * 10$ NW-SE

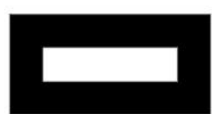

$10 * 40 \mathrm{EW}$

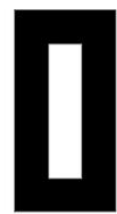

$40 * 10 \mathrm{NS}$

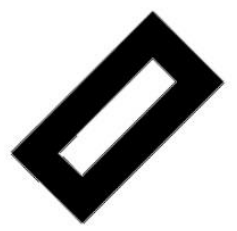

$10 * 40$ NE-SW

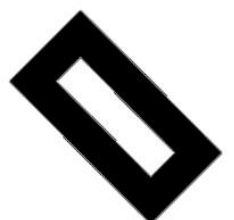

40*10 NW-SE

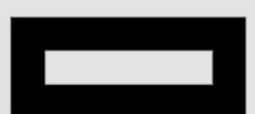

$10 * 50 \mathrm{EW}$

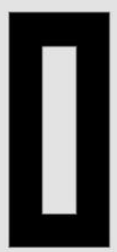

$50 * 10 \mathrm{NS}$

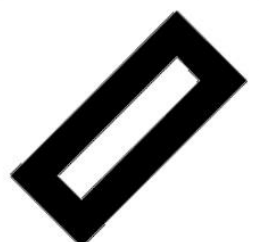

$10 * 50$ NE-SW

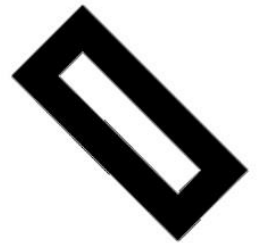

50*10 NW-SE

Figure 1: The courtyards simulated with different orientations and lengths.

Next, the models with the highest and lowest amount of discomfort hours (as reference models) were then selected for further simulations. These two models were also simulated for the W+ 2050 climate scenario showing how thermal comfort in these dwellings changes with climate change. The weather data file used for the future climate scenario simulations is also explained in [25]. Furthermore, four heat mitigation strategies are applied to the reference models. These strategies include: increasing the albedo (or reflection coefficient) of surfaces, using vegetation on the roof and on the ground of the courtyards, and finally using gravel on the roofs and within the courtyards. 
In the next step, the thermal behaviour of the zones located on different positions (North, South, East and West) of the reference models will be analysed (Figure 2). Then, the effect of different roofs on the Southern zone in summer $\left(16^{\text {th }}-23^{\text {rd }}\right.$ of June $)$ and winter $\left(16^{\text {th }}-23^{\text {rd }}\right.$ of December) will be addressed in one of the reference models.

North-South

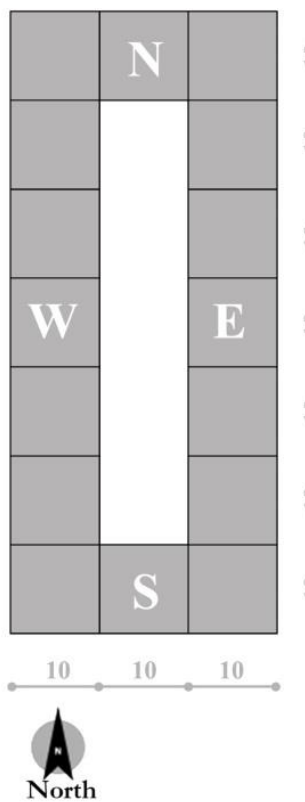

East-West

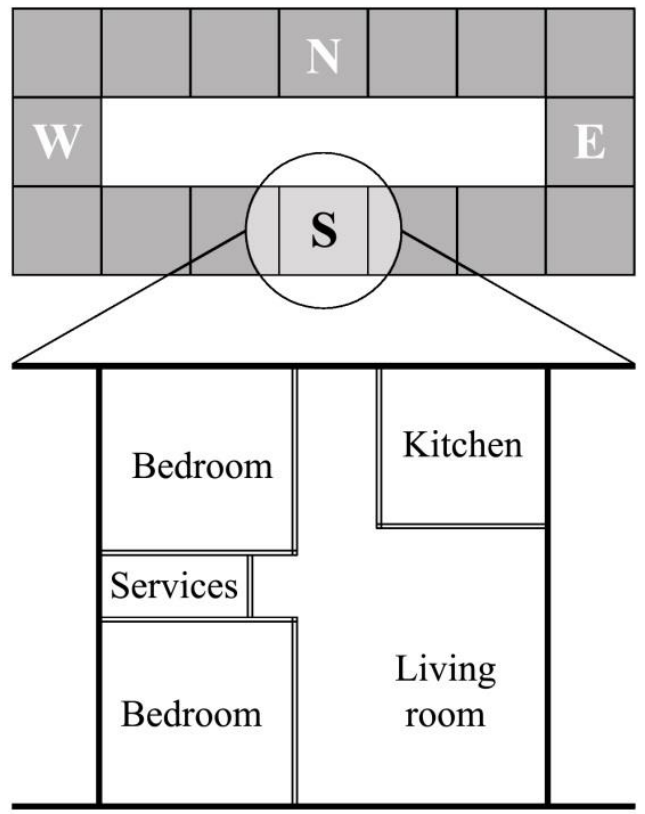

Figure 2: The studied reference models (N-S and E-W), and the interior plan of the Southern zone/dwelling.

In phase 2 , a $1 / 100$ scale model of one of the reference courtyards (10*50 EW) was made. This was mainly to test the effect of different materials on the roof and on courtyard ground in a controlled situation. The only variable in this step is the materials used for paving the roof and the ground of the model. The results of the scale model measurements cannot be directly compared to real situations but can only be used for comparing the effects of different surface materials. A 1000 Watt halogen light was used as the heat source, and a 22 Watt desk fan was used to generate wind (Figure 3). The position of the lamp was similar to the position of the sun on $21^{\text {st }}$ of June in Delft, the Netherlands. The fan blew air to the model from the south-west to simulate the prevailing wind in the Netherlands. Four materials were used to cover the roof and the ground of the courtyard model: black cardboard, white cardboard, white gravel and grass (with soil). The gravel and grass were tested two times: dry and wet. Each experiment took 12 hours; 6 hours with the lamp and fan on, and 6 hours with the fan on only. The air temperature was recorded within the courtyard and inside the model (on the North, South, East and West side) with iButtons type DS1923-F5+ temperature sensors. The accuracy of this type of data logger is $\pm 0.5^{\circ} \mathrm{C}$. The experiments were done in April 2014 in a free running mode lab; and therefore, not influenced by heating or cooling systems. The spectral reflectivity and albedo of the materials were also measured with a spectrophotometer (Perkin Elmer Lambda 950- UV/Vis/NIR). 

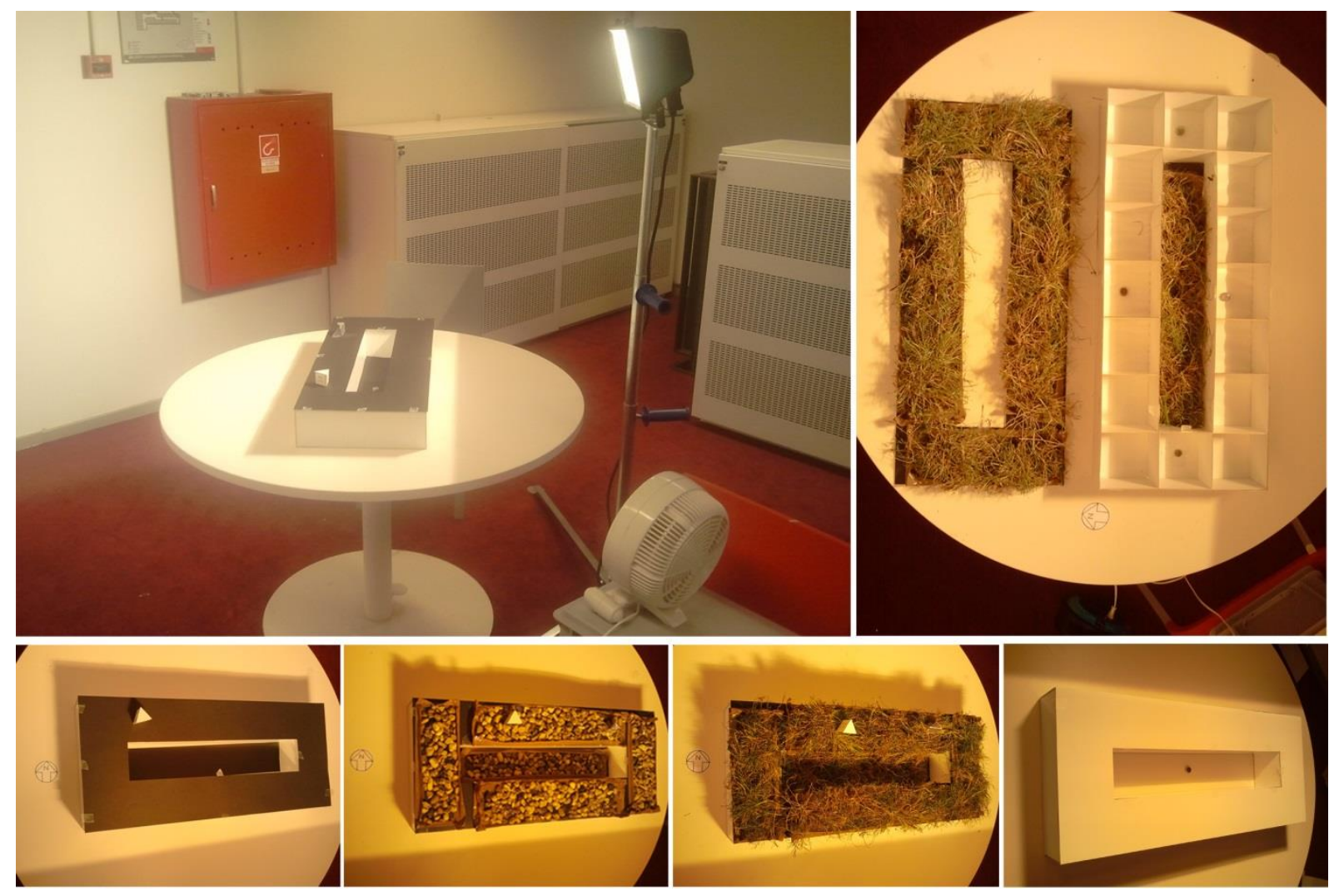

Figure 3: Up left: the scale model experiment with the halogen light and fan. Up right: the sensors placed in the four sides of the model. Down from left to right: black cardboard, gravel, grass and white cardboard.

In phase 3, an actual courtyard house in Delft (the Netherlands) was monitored from April $19^{\text {th }}$ till May $31^{\text {st }}$. The aim of this monitoring was to validate DesignBuilder as the simulation software used in this paper (phase 1). The monitoring was done when the courtyard house was in free running mode (with only full mechanical ventilation with heat recovery operating). Thus, no heating or cooling system affected the indoor temperature. The measured house is $11.5 \mathrm{~m} * 7.7 \mathrm{~m}$. The air temperature was measured with Plugwise Sense data loggers with a measurement interval of one hour in four rooms (living room, kitchen, master bedroom and small bedroom) and inside the courtyard. The accuracy of these data loggers is $\pm 0.3^{\circ} \mathrm{C}$. The measurement results were, then, compared with the simulation results of the house in DesignBuilder.

The $\mathrm{U}$-values of the walls and glass are 0.28 and $1.7 \mathrm{~W} / \mathrm{m}^{2} \mathrm{~K}$, respectively. The window to wall ratio is $63 \%$. Figure 4 shows the location and a view of the courtyard. 

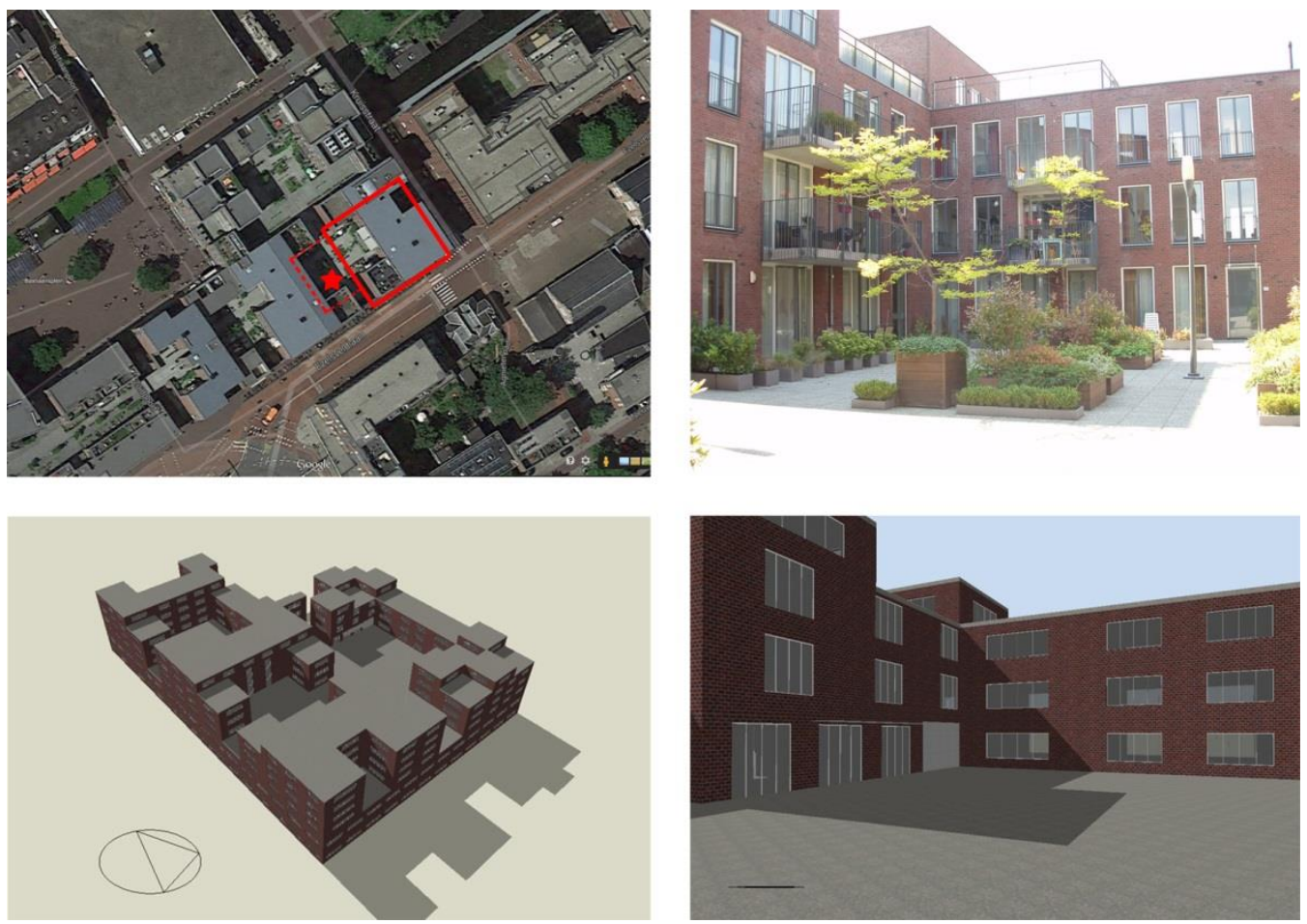

Figure 4: Up left: An aerial view of the field measurement. The measured courtyard house is highlighted with a star. Up right: The courtyard view. Down left: The whole model of the residential complex in DesignBuilder. Down right: The same view of the courtyard in the computer model.

\subsection{Energy modelling}

DesignBuilder as a graphical interface for EnergyPlus was selected for the simulations. Developed by US Department of Energy, EnergyPlus relies on key elements of both the DOE-2 and BLAST programs. Some key features that this research needed (and EnergyPlus is capable of doing) are: text based weather input files, ground heat transfer modelling and green roof modelling. The green roof model for EnergyPlus was developed by Sailor [26] based on preliminary sets of parametric tests in Florida, Chicago and Houston. This model considers long and short wave radiative exchanges, plant canopy effects on convective heat transfer, evapotranspiration from the soil and plants, and heat conduction (and storage) in the soil layer. Table 2 shows the data for the green roof model used in the simulations.

Table 2: The data used for the simulation of the green roof in this research.

\begin{tabular}{|l|l|}
\hline Height of plants $(\mathrm{m})$ & 0.10 \\
\hline Leaf area index (LAl) & 5.00 \\
\hline Leaf reflectivity & 0.22 \\
\hline Leaf emissivity & 0.95 \\
\hline Minimum stomata resistance $(\mathrm{s} / \mathrm{m})$ & 100 \\
\hline $\begin{array}{l}\text { Max volumetric moisture content of the soil layer } \\
\text { (saturation) }\end{array}$ & 0.50 \\
\hline $\begin{array}{l}\text { Min (residual) volumetric moisture content of the } \\
\text { soil layer }\end{array}$ & 0.01 \\
\hline Initial volumetric moisture content of the soil layer & 0.15 \\
\hline
\end{tabular}




\subsection{Thermal comfort model}

In this paper, thermal comfort is calculated based on the ASHRAE 55-2010 standard [27]. This standard is based on the largest database with measured results $(21,000$ measurements) from Australia to Canada. According to this standard, the thermal comfort temperature is calculated as:

$T_{C O}=0.31 \times T_{r e f}+17.8$

Where $T_{C O}\left[{ }^{\circ} \mathrm{C}\right]$ is comfort temperature; and $T_{r e f}\left[{ }^{\circ} \mathrm{C}\right]$ is the prevailing mean outdoor air temperature (for a time period between the last 7 to 30 days before the day in question). The range of thermal comfort bounds is $3.5^{\circ} \mathrm{C}$ upper and lower of $T_{C O}$. The measurements and surveys that were done to create the database that resulted in this standard were done mostly in office buildings. Due to the lack of a standard for dwellings, the mentioned standards were used [28].

\subsection{Climate of the Netherlands}

The climate of the Netherlands is known as a temperate climate based on the climatic classification of Köppen-Geiger [29]. The prevailing wind is South-West, and the mean annual dry bulb temperature is $10.5^{\circ} \mathrm{C}$. For the simulations, the hourly weather data of De Bilt $\left(52^{\circ} \mathrm{N}, 4^{\circ} \mathrm{E}\right)$ that represents for the Netherlands is used [25].

The Royal Dutch Meteorological Institute (KNMI) has translated the IPCC climate scenarios for the Netherlands in 2050 [30]. Taleghani, et al. [25] has explained the KNMI '06 climate scenarios and how from these scenario's future weather data files can be created. The severest scenario, $\mathrm{W}_{+}$(warm scenario with an average $+2^{\circ} \mathrm{C}$ temperature increase), was selected in this paper to study thermal comfort in the future ${ }^{2}$.

For phase 3, the simulation of the real courtyard house in Delft, the weather data was taken from a KNMI weather station located at Rotterdam - The Hague Airport about 8 km southeast of the courtyard house.

\footnotetext{
2 Recently, in May 2014, KNMI published new climate scenarios for the Netherlands, the so-called KNMI'14 climate scenarios. Because this study was undertaken before these new scenarios were published, the previous scenarios from 2006 were used.
} 


\section{Results}

\subsection{Phase 1: Parametric simulations}

\subsubsection{Courtyards with different orientations}

In this phase of the study, 18 urban courtyard blocks were simulated for a summer week. The courtyard models vary in length and width from 10 to $50 \mathrm{~m}$ with steps of $10 \mathrm{~m}$; and have four main orientations N-S, E-W, NW-SE, and NE-SW. In Figure 5, the amount of achieved solar radiation is illustrated for the N-S and E-W models (a) and for NW-SE and NE-SW models (b). The corresponding average indoor ventilation rates (c and d), average indoor operative temperatures (e and f), and numbers of discomfort hours are shown respectively with the same axis scale for the same models ( $g$ and $h$ ).

The simulated week contains the longest days in a year. On $21^{\text {st }}$ of June, the sun rises at 5:18h and sets at 22:03h (17:45 hours in total) in De Bilt in the Netherlands. During these long days, the sun rises from the North-East and sets in the North-West. The maximum sun angle is $61^{\circ}$ on $21 \mathrm{st}$ of June at 12 o'clock solar time (around 13:41 h De Bilt local time). This sun path affects mostly eastern façades (in the morning), roofs and southern façades (at noon) and western façades (in the afternoon and evening). With this principle, buildings with long orientations through N-S have higher solar heat gains, and E-W orientation lower. This phenomenon is visible in Figure 5- a) and b). Among the simulated models, the maximum total solar gain is received by the $50^{*} 10 \mathrm{~N}-\mathrm{S}$ block $\left(289 \mathrm{Wh} / \mathrm{m}^{2}\right)$, and the minimum by the $10 * 50 \mathrm{E}-\mathrm{W}$ block $\left(231 \mathrm{Wh} / \mathrm{m}^{2}\right)$.

Figure 5-c) and d) show the average indoor ventilation rate of the models. The prevailing wind in the Netherlands is South-West (from the North Sea). This direction makes the models with NW-SE direction more suitable for natural ventilation. Having a look at the figure, the highest average ventilation rate is achieved by the $10 * 50 \mathrm{NW}-\mathrm{SE}$ model $(0.82$ $\mathrm{ac} / \mathrm{h})$, and the lowest by the $10^{*} 50 \mathrm{NE}-\mathrm{SW}$ model $(0.70 \mathrm{ac} / \mathrm{h})$.

To calculate thermal (dis)comfort, the operative temperature of the models is needed. Figures 5-e) and f) summarise the average operative temperature of the models during the simulated week. The warmest model corresponds to the model that receives the most solar radiation, which is the $50^{*} 10 \mathrm{~N}-\mathrm{S}$ model. In contrast, the coolest model is the $10^{\star} 50 \mathrm{E}-\mathrm{W}$ model corresponding with the least solar radiation entry.

Based on the simulations, the percentage of discomfort hours are calculated for each model. The $50 * 10 \mathrm{~N}-\mathrm{S}$ model shows the most discomfort hours (with $90 \%$ of the time uncomfortable), and the $10 * 50 \mathrm{E}-\mathrm{W}$ model the least (with $50 \%$ of the time uncomfortable). The rotated models $10 * 50 \mathrm{NW}-\mathrm{SE}$ and NE-SW also have a high percentage of discomfort hours ( $74 \%$ and $85 \%$, respectively). This shows that NW-SE orientation is more comfortable among the rotated courtyards. 

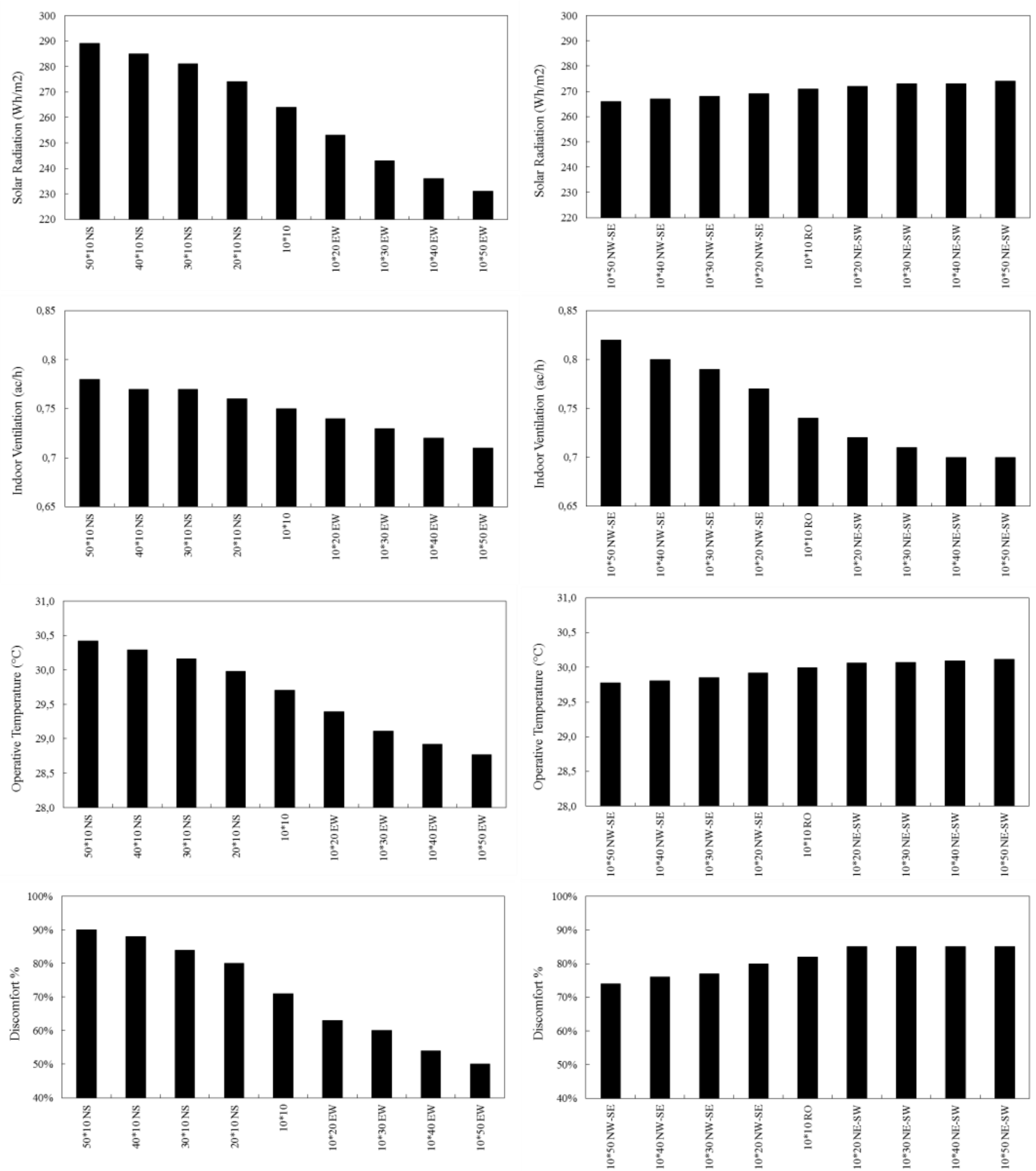

Figure 5: a,b) Solar radiation received through the windows; $c, d)$ Indoor ventilation; e,f) Operative temperature; and g,h) Percentage of thermal discomfort during the summer week. 


\subsubsection{Future climate scenario and heat mitigation strategies}

Climate change is likely to have a significant effect on the cooling demand of buildings. The severest climate scenario ( $\mathrm{W}+$ ) for the Netherlands in 2050 according to the KNMI '06 climate scenario's is used to estimate thermal comfort in dwellings alongside an urban courtyard in the future. First, simulations are run based on the reference models selected from the previous simulations $(50 * 10 \mathrm{~N}-\mathrm{S}$ and $10 * 50 \mathrm{E}-\mathrm{W}$, respectively). These reference models are selected based on the maximum and minimum percentage of thermal discomfort found in the previous section. Then, heat mitigation strategies are applied to the reference models to test their effects on thermal comfort. The heat mitigation strategies include: increasing the albedo (or reflection coefficient) of surfaces, using vegetation on the roof and on the ground of the courtyards and finally using gravel on the roofs and within the courtyards (Table 3 and 4).

According to the future climate scenario $\mathrm{W}+$ for 2050 , the outdoor air temperature will increase and as a consequence leading to more discomfort hours. Although the solar radiation in 2050 is assumed to be the same as in the current climate ${ }^{3}$, the operative temperature in the reference models $10^{\star} 50 \mathrm{E}-\mathrm{W}$ and $50^{\star} 10 \mathrm{~N}-\mathrm{S}$ increased by $2.2^{\circ} \mathrm{C}$ and $2.0^{\circ} \mathrm{C}$ on average, respectively. This increase leads to a situation in which $79 \%$ and $100 \%$ of the time is thermally uncomfortable in the corresponding models.

Application of the heat mitigation strategies leads to a lower number of discomfort hours. The first strategy tested is increasing the albedo of the outer surfaces (roof and facades). The albedo of the facades and roof in the reference models is 0.20 and 0.10 respectively, and both of them are increased to 0.93 , which corresponds to an added layer of white plaster. The increased albedo leads to more solar radiation being reflected and less being absorbed. This change decreases the discomfort hours by $6(\mathrm{E}-\mathrm{W})$ and 14 percent points $(\mathrm{N}-\mathrm{S})$.

The second strategy is using vegetation on the roof as a green roof. Green roofs may cool the indoor environment due to their higher albedo (than conventional bituminous roofs) and their evapotranspiration effect. The use of this strategy leads to $9(E-W)$ and 13 percent point $(\mathrm{N}-\mathrm{S})$ reduction of discomfort. The other similar strategy is using vegetation on the ground of the courtyard. Vegetation only on the ground reduces discomfort by 7 (E-W) and 5 percent points (N-S). This strategy seems to be less effective than the green roof because the vegetation on the roof directly affects the surface temperature of the roof, but on the ground only influences the reflected solar radiation. Combining vegetation on the roof and on the ground of the courtyard leads to a $9(\mathrm{E}-\mathrm{W})$ and 19 percent point $(\mathrm{N}-\mathrm{S})$ reduction in discomfort. This reduction is more than the separate strategies but not the sum of them.

The last strategy is using gravel on the roof and on the ground of the courtyard. Gravel has high reflectivity and higher thermal mass than bituminous roofs. This strategy showed a $7(\mathrm{~N}-$ S) and 18 percent point (E-W) discomfort reduction.

\footnotetext{
${ }^{3}$ Because of changes in wind patterns, cloud cover may be different in 2050 as compared to 1981-2010. However, because of a lack of future projections cloud cover and solar radiation intensities are assumed the same in the future scenario.
} 
Table 3: Operative temperatures and percentage of discomfort hours in the N-S model.

\begin{tabular}{|c|c|c|c|c|c|}
\hline & $\operatorname{Max}\left({ }^{\circ} \mathrm{C}\right)$ & Mean $\left({ }^{\circ} \mathrm{C}\right)$ & $\operatorname{Min}\left({ }^{\circ} \mathrm{C}\right)$ & Discomfort (\%) \\
\hline \multicolumn{2}{|c|}{ Reference N-S model } & 35.9 & 30.4 & 25.8 & 90 \\
\hline \multirow{3}{*}{ Roof } & Green & 35.3 & 29.8 & 25.1 & 77 \\
\hline & Gravel & 36.7 & 30.1 & 24.5 & 71 \\
\hline & Plaster & 35.3 & 29.8 & 25.2 & 76 \\
\hline \multirow{2}{*}{ Ground } & Green & 35.6 & 30.2 & 25.5 & 85 \\
\hline & Gravel & 37.2 & 30.5 & 24.7 & 79 \\
\hline \multirow{2}{*}{$\begin{array}{l}\text { Roof \& } \\
\text { ground }\end{array}$} & Green & 35.1 & 29.6 & 25.0 & 71 \\
\hline & Gravel & 36.7 & 30.2 & 24.6 & 72 \\
\hline
\end{tabular}

Table 4: Operative temperatures and percentage of discomfort hours in the E-W model.

\begin{tabular}{|c|c|c|c|c|c|}
\hline & $\operatorname{Max}\left({ }^{\circ} \mathrm{C}\right)$ & Mean $\left({ }^{\circ} \mathrm{C}\right)$ & $\operatorname{Min}\left({ }^{\circ} \mathrm{C}\right)$ & Discomfort (\%) \\
\hline \multicolumn{2}{|c|}{ Reference E-W model } & 33.8 & 28.8 & 24.5 & 50 \\
\hline \multirow{3}{*}{ Roof } & Green & 33.3 & 28.2 & 24.0 & 41 \\
\hline & Gravel & 34.6 & 28.6 & 23.4 & 43 \\
\hline & Plaster & 34.8 & 28.8 & 23.5 & 44 \\
\hline \multirow{2}{*}{ Ground } & Green & 34.6 & 28.7 & 23.5 & 43 \\
\hline & Gravel & 35.3 & 29.0 & 23.6 & 48 \\
\hline \multirow{2}{*}{$\begin{array}{l}\text { Roof \& } \\
\text { ground }\end{array}$} & Green & 34.1 & 28.1 & 23.0 & 41 \\
\hline & Gravel & 34.6 & 28.7 & 23.5 & 43 \\
\hline
\end{tabular}

Table 5 shows the reductions of discomfort hours (in percentage points) by means of the aforementioned heat mitigation strategies as average of the two models. The reductions are calculated based on the differences with the corresponding reference models. The results show that the effect of the roof is stronger than of the courtyard pavement. Moreover, the maximum cooling effect happens when the roof and the courtyard are vegetated.

Table 5: The average reductions of discomfort hours in the two models.

\begin{tabular}{|c|l|c|}
\hline \multicolumn{2}{|c|}{} & Discomfort reduction (\%) \\
\hline \multirow{3}{*}{ Roof } & Green & 11 \\
\cline { 2 - 3 } & Gravel & 13 \\
\cline { 2 - 3 } & Plaster & 10 \\
\hline \multirow{2}{*}{ Ground } & Green & 6 \\
\cline { 2 - 3 } & Gravel & 6.5 \\
\hline \multirow{2}{*}{$\begin{array}{l}\text { Roof \& } \\
\text { ground }\end{array}$} & Green & 14 \\
\cline { 2 - 3 } & Gravel & 12.5 \\
\hline
\end{tabular}




\subsubsection{The position effect}

In this part of the study, thermal comfort is studied in dwellings with different position/orientation and floor inside the urban courtyard blocks (E-W and N-S). First dwellings in four main orientations, North, South, East and West, are compared, and then the average of all dwellings on each of the three floors $\left(1^{\text {st }}, 2^{\text {nd }}\right.$ and $3^{\text {rd }}$ storey).

Figure 6 (a and c) shows how dwellings with different orientation inside the urban courtyard blocks behave differently during the summer week. The dwellings on the Western side of the blocks are the hottest because they are warmed from the early morning $(\approx 5: 20)$, and receive direct sun during the before noon till evening (till $\approx 22: 00$ during the simulated summer week). The dwellings on the Eastern side of the blocks also receive a long period of direct sun from the early morning till evening. The dwellings located on the North and South side have the lowest indoor operative temperature because the sun angle is high during this week. Analysis of the results shows that the Northern, Southern, Eastern and Western dwellings in the $\mathrm{E}-\mathrm{W}$ model have $31 \%, 31 \%, 91 \%$ and $99 \%$ of discomfort hours, respectively. Corresponding amounts for the dwellings in the N-S model are $44 \%, 51 \%, 94 \%$ and $100 \%$.

The zones located on different levels have different thermal behaviour. Figure 6 ( $b$ and $d)$ shows a comparison of dwellings on the Southern side of the urban courtyard blocks on the three different stories of the courtyard models. The ground floors of the models are the coolest and the $2^{\text {nd }}$ floor the warmest. The ground floors of the models are in touch with the ground. The average annual temperature of the ground is around $10^{\circ} \mathrm{C}$ in the Netherlands. This makes the ground floors of the models cooler than the upper floors. In contrast, the $2^{\text {nd }}$ floors of the models are right below the roof. This roof surface heats the $2^{\text {nd }}$ floors making them warmer than the others. Likewise, the number of discomfort hours during the simulated week is higher on the upper levels. The calculated discomfort hours for the dwellings on the Southern side of the building on the ground, $1^{\text {st }}$ and $2^{\text {nd }}$ floor of the E-W model are $21 \%, 32 \%$ and $42 \%$ respectively. These amounts for the $\mathrm{N}-\mathrm{S}$ model are $35 \%, 52 \%$ and $62 \%$, respectively. This shows that by increasing one level in the model, the number of thermal comfort hours decreases by almost 10 percent points. 


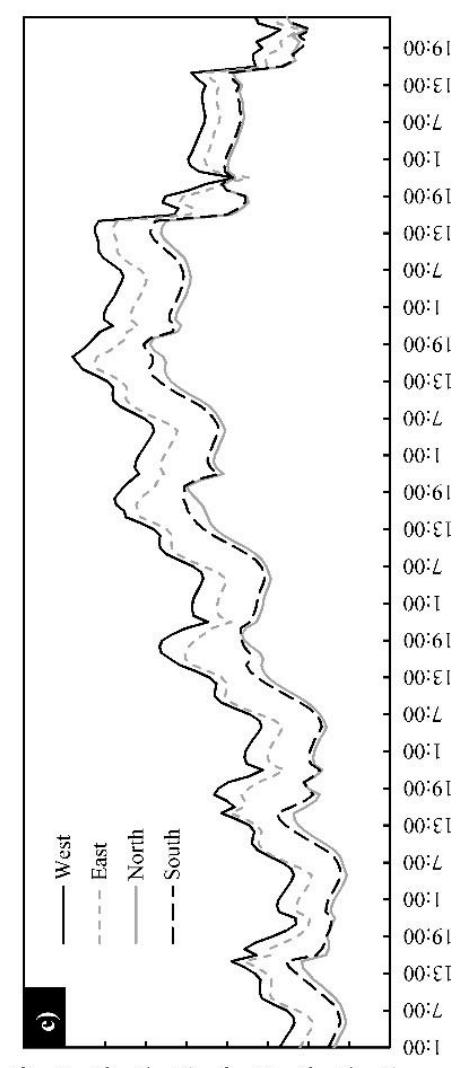

\&

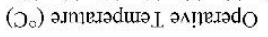

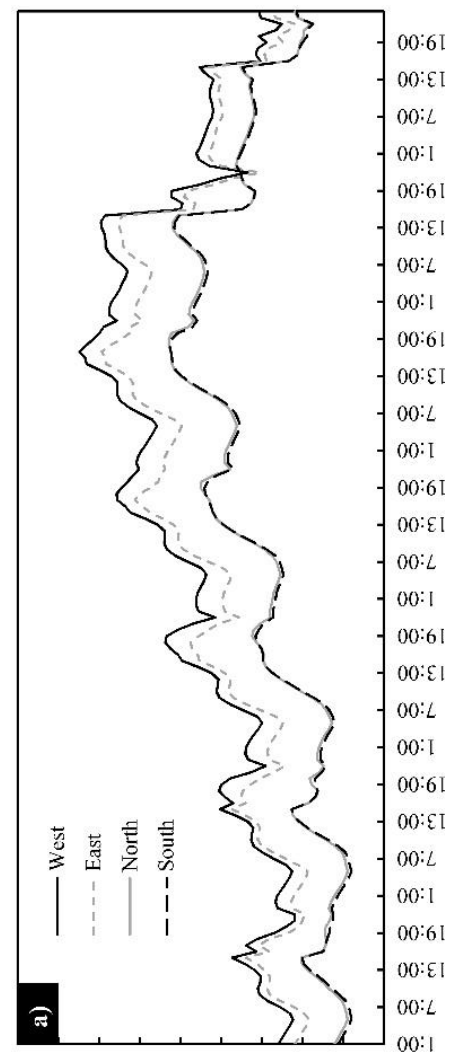

于 $\infty$ 品

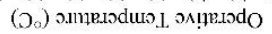

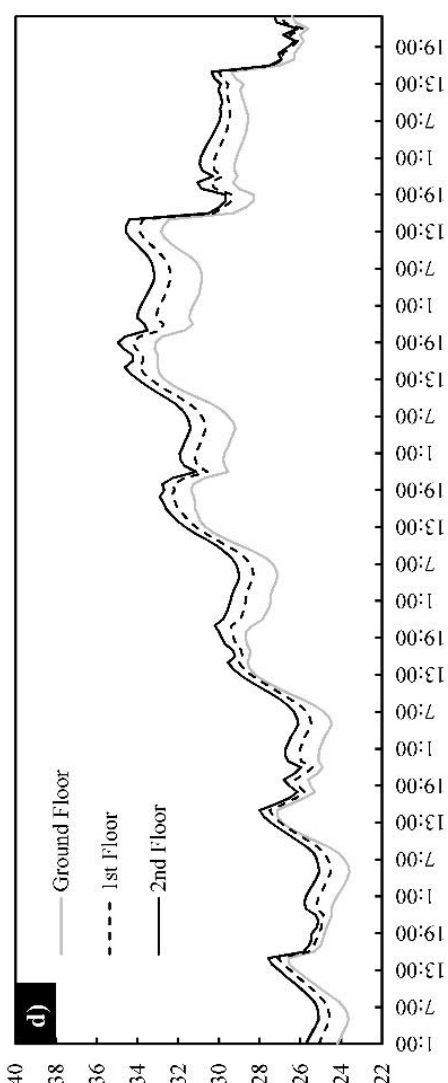

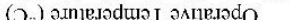

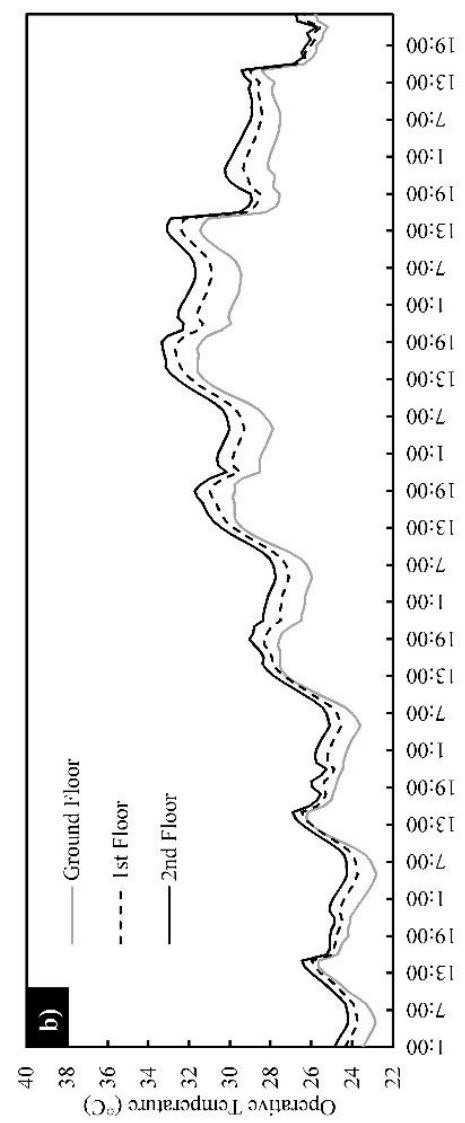

Figure 6: The operative temperature in zones/dwellings with different position and height in the $10 * 50$ E-W model ( $a$ and b); and in the 50*10 N-S model (c and d). 


\subsubsection{Detailed analysis of a single family house with different roofs}

In this part of the study, the effect of different roofs on thermal comfort is studied. To do this, a dwelling on the Southern side of the urban courtyard block located on top floor of the $10 * 50$ E-W model is selected for simulations. The building is simulated with 4 different roofs: a black (conventional), a white, a green (vegetated) and a grey (gravel) roof. The black roof is a typical roof with bituminous top layer. The white roof is finished with white plaster. The green roof is a vegetated roof with grass. The grey roof is covered with gravel. The simulations are run for the summer week ( $16^{\text {th }}$ till $23^{\text {rd }}$ of June), and also for a winter week (16 ${ }^{\text {th }}$ till $23^{\text {rd }}$ of December). The winter week is simulated to check the effect of the roof during the winter. Several studies have shown that cool roofs (such as white and green roofs) can lead to additional heat loss and increased heating demand [23, 31, 32]. The simulations are done in a free running mode in winter (same as in summer) to not being influenced by the heating system. The zone as a home, is divided into different sub-zones and activities; two bedrooms, a kitchen, a toilet and bathroom, a living room and corridors.

The results show that the black roof (with the highest solar absorption) causes the highest indoor operative temperature among the models (Figure 7- a)). The white and green roofs have similar behaviour, and the gravel roof provides the lowest operative temperature. This could be due to the high albedo of the gravel and also its higher heat capacity. The average operative temperature of the model with these four roofs during the summer week is $28.4^{\circ} \mathrm{C}$, $27.7^{\circ} \mathrm{C}, 27.6^{\circ} \mathrm{C}$ and $27.3^{\circ} \mathrm{C}$ for the black, white, green and gravel roofs, respectively. The calculated amount of discomfort hours with these four roofs is $43 \%, 33 \%, 29 \%$ and $27 \%$, respectively. The operative temperature in the model during the winter week is illustrated in Figure 7- b). In winter, the roofs have very small differences with each other; nevertheless, the black roof leads to the higher operative temperature. The average operative temperature in the models is $12.2^{\circ} \mathrm{C}, 12.1^{\circ} \mathrm{C}, 12.1^{\circ} \mathrm{C}$ and $12.0^{\circ} \mathrm{C}$ for the black, the green, the white and the gravel roof, respectively.

To sum up, the gravel roof leads to the minimum indoor operative temperature in summer, whereas the black roof leads to the highest in winter (Table 6). 

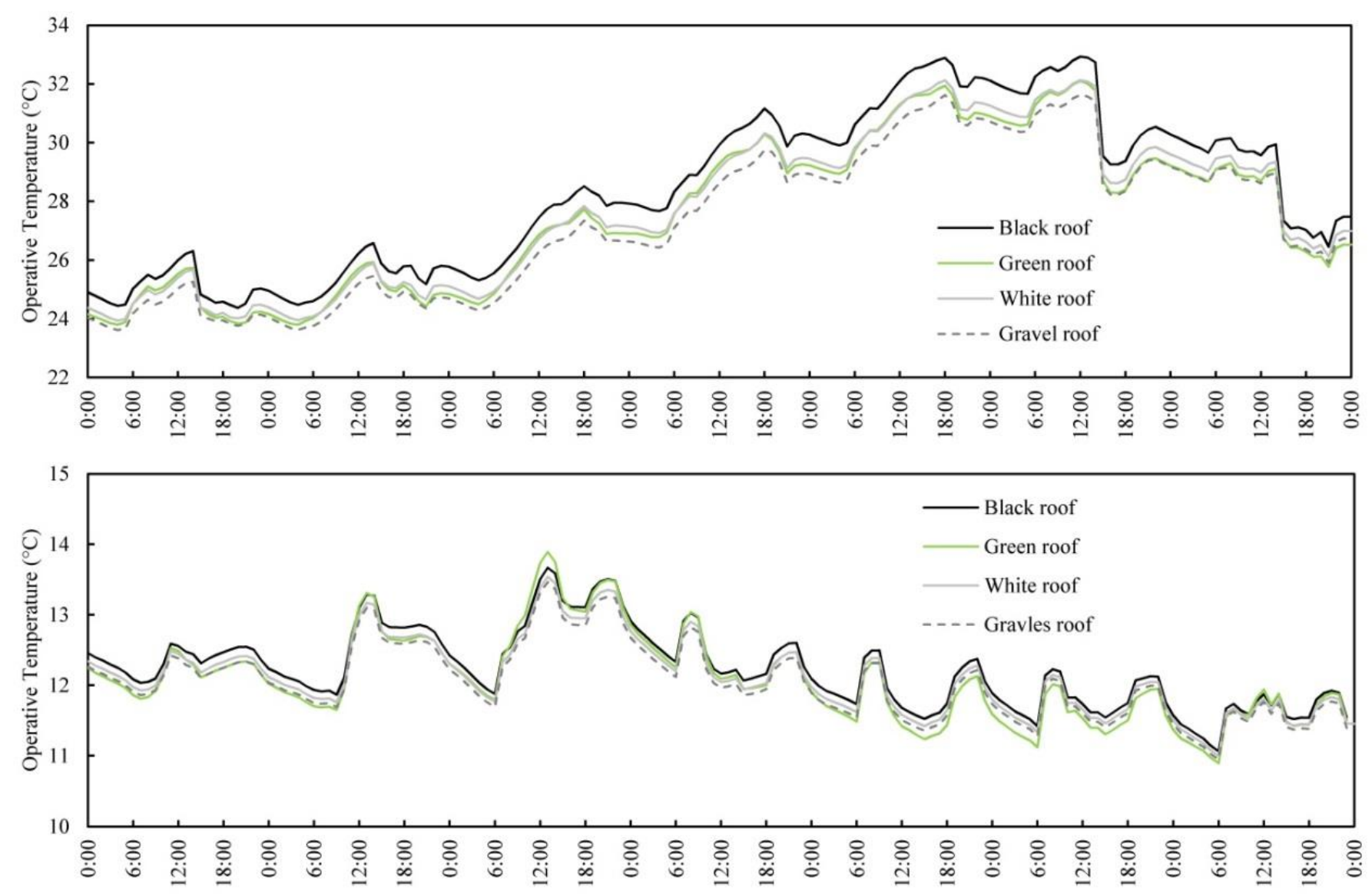

Figure 7: The average operative temperatures of the house in summer (top), and winter (down).

Table 6: The operative temperatures of the model with different roofs.

\begin{tabular}{|l|c|l|l|l|l|l|l|}
\hline & R Value & \multicolumn{3}{|c|}{ Summer week } & \multicolumn{3}{c|}{ Winter week } \\
\cline { 3 - 8 } & $\left(\mathrm{m}^{2} \mathrm{~K} / \mathrm{W}\right)$ & $\operatorname{Max}\left({ }^{\circ} \mathrm{C}\right)$ & Mean $\left({ }^{\circ} \mathrm{C}\right)$ & $\operatorname{Min}\left({ }^{\circ} \mathrm{C}\right)$ & Max $\left({ }^{\circ} \mathrm{C}\right)$ & Mean $\left({ }^{\circ} \mathrm{C}\right)$ & Min $\left({ }^{\circ} \mathrm{C}\right)$ \\
\hline Black roof & 3.014 & 32.9 & 28.4 & 24.4 & 13.7 & 12.2 & 11.1 \\
\hline Green roof & 2.057 & 32.1 & 27.6 & 23.8 & 13.9 & 12.1 & 10.9 \\
\hline White roof & 3.039 & 32.1 & 27.7 & 23.9 & 13.5 & 12.1 & 11.0 \\
\hline Gravel roof & 3.042 & 31.6 & 27.3 & 23.6 & 13.5 & 12.0 & 10.9 \\
\hline
\end{tabular}

\subsection{Phase 2: Scale model experiment}

The results of phase 1 were based on the computer simulations. To validate parts of the results, an experiment on a scale model was done. The experiment focused on the effect of the different materials used in the simulations (black, green, white and gravel surfaces). Thus, this complementary phase was added to the research. First, the albedo of the materials used in the scale model experiment was measured. The albedo of the black cardboard is 0.054 , of the white cardboard 0.832 and of the grass in dry mode 0.387 . The 
albedo of the gravel could not be measured; but based on Santamouris [33] it should be around 0.72 .

Figure 8 shows the normalised air temperature within the courtyard model and inside the model after 6 hours (heating process with $1000 \mathrm{~W}$ lamp and $22 \mathrm{~W}$ fan) and after 12 hours (cooling down process with $22 \mathrm{~W}$ fan only). To get these normalised values, the ambient air temperature of the lab was subtracted from the measured air temperatures. A value above zero thus means that the air above the surface is warmer than the lab air. The temperatures are plotted after 6 and 12 hours. The lamp (representing the sun) was turned off after 6 hours, and the fan (as the wind source) was turned off after 12 hours, at the end of each experiment.

Considering the indoor environment, the average indoor temperature of the four sides of the scale model (subtracted from the measured lab air temperatures) is illustrated in Figure 8-a. After 6 hours, the indoor environment below the black roof has the highest normalised air temperature $\left(+2.0^{\circ} \mathrm{C}\right)$, and the indoor environment below the wet grass roof the lowest ($1.1^{\circ} \mathrm{C}$ ). The wet gravel provides the second coolest indoor environment. This experiment on dry and wet gravel shows that the dry gravel roof has $0.4^{\circ} \mathrm{C}$ higher temperature than the white roof; however, the wet gravel roof provides a $1.4^{\circ} \mathrm{C}$ cooler indoor environment than the white roof. This shows that the effect of evaporation is stronger than the effect of albedo. After $12 \mathrm{~h}$, the wet grass led to the coolest indoor environment $\left(-2.5^{\circ} \mathrm{C}\right)$ while the other models had a more or less similar temperature which was close to or just below the ambient air temperature.

Regarding the courtyard temperatures (Figure 8-b), the dry gravel and the black pavement have the highest normalised air temperature after $6 \mathrm{~h}\left(+1.9^{\circ} \mathrm{C}\right.$ and $+1.7^{\circ} \mathrm{C}$, respectively). Comparing the dry gravel and grass with their wet counterpart, the dry pavements lead to a higher temperature after both 6 and 12 hours. When the gravel pavement is irrigated, the air temperature inside the courtyard decreases with $+4.2^{\circ} \mathrm{C}$; if the grass is irrigated, this decrease is $+2.9^{\circ} \mathrm{C}$. After 12 hours, the wet grass pavement results in the lowest courtyard temperature $\left(-3.2^{\circ} \mathrm{C}\right)$ among the others. The other cool pavement material was the wet gravel with $-2.9^{\circ} \mathrm{C}$. The experiment on the microclimate of the courtyard also shows that the gravel and the white cardboard (with highest albedos) do not necessarily provide the coolest environment. The evaporative cooling effect of water made the courtyard with wet grass and wet gravel the coolest microclimates.

It should be noted that this phase of the study was based on the experiment on a cardboard scale model. Although these results should be taken with some caution, this study showed that the albedo of the materials directly affect the indoor temperature. The added value of this study was to show that an irrigated cool roof (covered with gravel or grass) has a much higher cooling effect than the dry equivalent. 

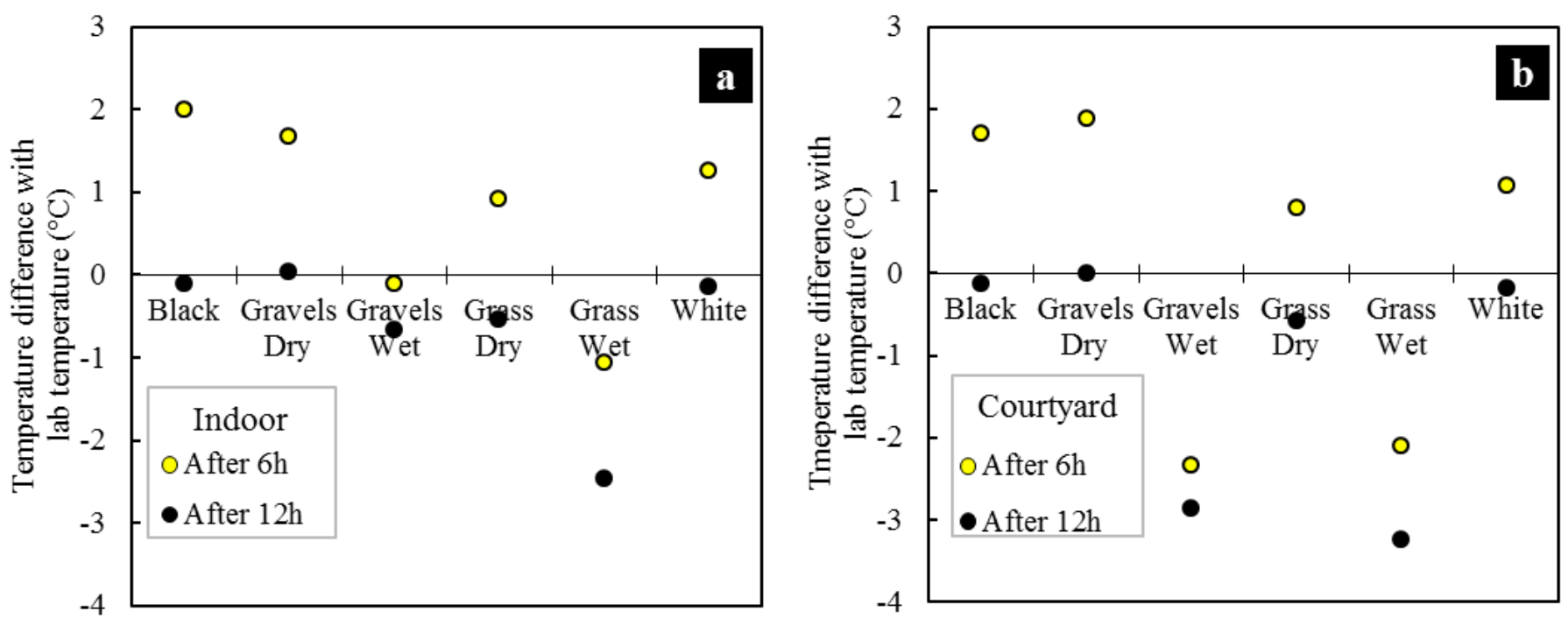

Figure 8: Temperature differences inside the scale model (average of four data loggers on the North, South, East and West side of the model) (a), and within the courtyard (b).

\subsection{Phase 3: An actual courtyard house experiment}

In this third phase, the thermal behaviour of an actual courtyard house in Delft (the Netherlands) is studied. Four data loggers recorded the air temperature of the living room, the kitchen, the master bedroom and a small bedroom from $1^{\text {st }}$ till $31^{\text {st }}$ of May. Another data logger measured the air temperature of the courtyard from $19^{\text {th }}$ of April till $31^{\text {st }}$ of May. The courtyard house is also modelled and simulated in DesignBuilder. The measured and simulated results are compared and plotted in Figure 9. The aim of this third phase is to validate the results of DesignBuilder, and see how well it predicts air temperature.

As shown, the simulated indoor temperatures have more fluctuations than the measured data. This is expected to be due to the higher thermal mass in the actual house that keeps the temperature more stable. The root mean square deviations (RMSD) between the measured and simulated temperatures in the living room, kitchen, master bedroom and small bedroom are: $0.80^{\circ} \mathrm{C}, 0.88^{\circ} \mathrm{C}, 0.85^{\circ} \mathrm{C}$ and $1.12^{\circ} \mathrm{C}$, respectively; and $0.91^{\circ} \mathrm{C}$ on average. Considering that the data loggers had an inaccuracy of $\pm 0.3^{\circ} \mathrm{C}$, this small difference is acceptable for the comparative studies done in phase 1 of this study.

The courtyard temperature is also compared to the nearest available KNMI weather station (Rotterdam-The Hague Airport) in Figure 9-e left. The maximum temperature that happened in the Delft courtyard was $26.8^{\circ} \mathrm{C}$ and at the airport $26.0^{\circ} \mathrm{C}$, both at $14: 00 \mathrm{~h}$. The minimum temperatures were $6.8^{\circ} \mathrm{C}$ (at $04: 00 \mathrm{~h}$ ) and $1.5^{\circ} \mathrm{C}($ at $03: 00 \mathrm{~h}$ ) in the courtyard and at the airport, respectively. This shows that the courtyard in general has a warmer microclimate than the airport. This could be due to the urban heat island effect because the courtyard is in the city centre, and the airport is located in the suburbs. Moreover, the courtyard has a higher thermal mass and lower openness to the sky than the airport. Figure 9-e right also shows the average (averaged for all 31 days of May) temperature difference for each hour during a 24 hour period between the courtyard and the airport. Based on this graph, the 
courtyard in general has a higher temperature than the airport except during a few hours around sunrise. The higher thermal mass accumulates the heat during the day and releases it at night. As a result the highest temperature difference occurs in the evening about 2 hours before sunset (19:00 h). To sum up, the average air temperature in the courtyard is $1.5^{\circ} \mathrm{C}$ higher than at the airport. 

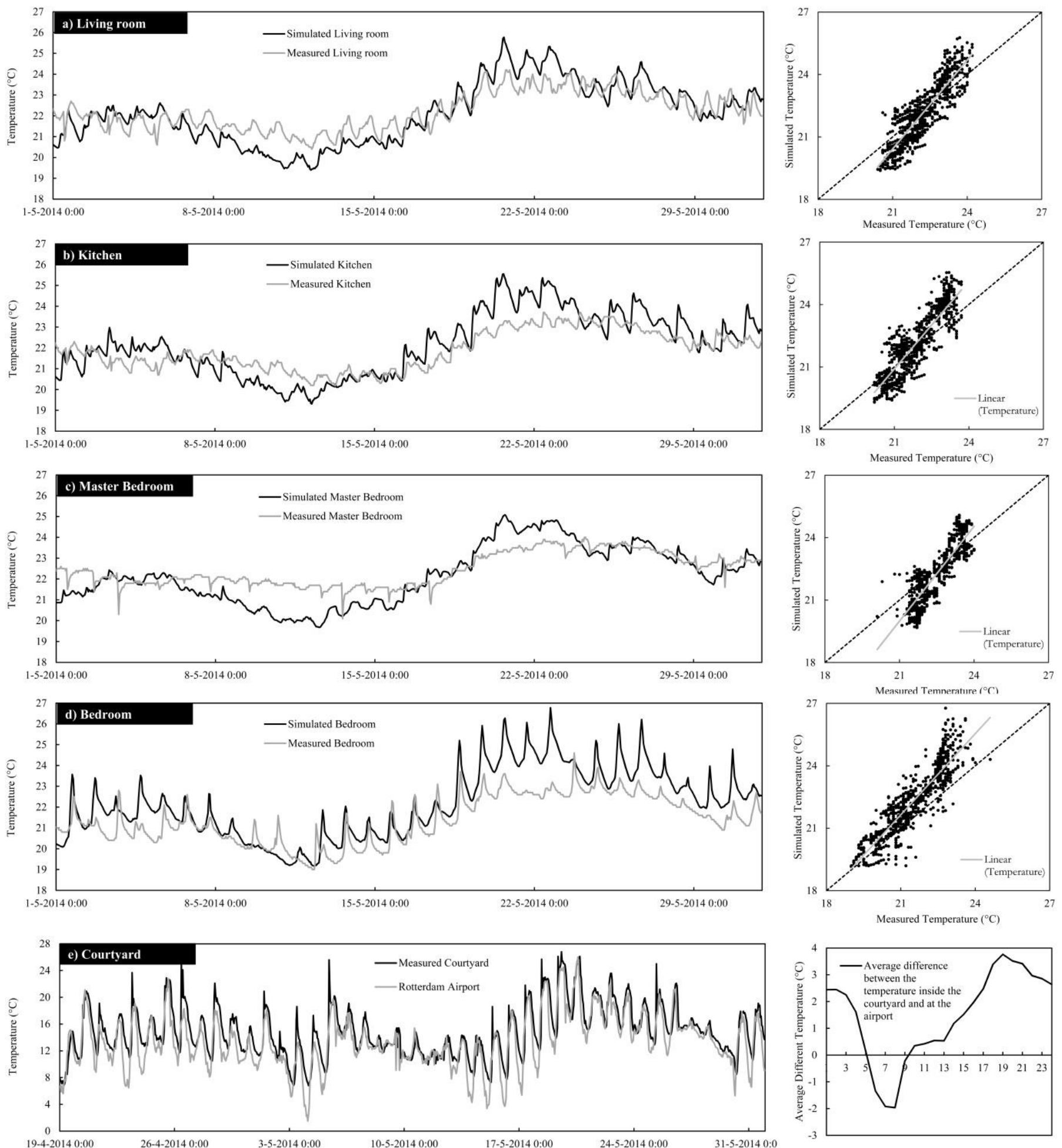

Figure 9: Compared temperatures of measurement and simulation in four rooms (a-d left) with their corresponding error plot (a-d right). The air temperatures of the courtyard and the airport are also compared (e left), and the average (averaged for all 31 days of May) temperature difference for each hour during a 24 hour period between the courtyard and the airport is illustrated in a graph (e right). 


\section{Conclusions}

This paper investigated the thermal behaviour of courtyard buildings with different orientations and elongations (sizes) in the Netherlands. The effect of different roofs and courtyard ground pavements were also tested in summer (and in a few cases in winter). The whole study was divided into three main phases:

In phase 1, eighteen courtyard buildings were simulated with DesignBuilder for a summer week. It was found that North-South and East-West orientations provide the least and most comfortable indoor environments, respectively. To optimise the thermal performance of these two models, different cool and highly reflective materials were simulated on the roof and as courtyard pavement. The results showed that the maximum reduction (14\%) in the number of discomfort hours happens when the roof and the courtyard ground are vegetated. Regarding the different thermal zones located in a courtyard, this paper showed that the number of discomfort hours is three times higher in dwellings on the eastern and western sides of an urban courtyard block rather than on the northern and southern sides, mainly because of the high sun angle in summer at 12 o'clock solar time. The number of discomfort hours in dwellings alongside an urban courtyard is higher on the higher floors than on the lower floors; by moving one floor up, the number of discomfort hours increases by 10 percent points. The warmest zones were found to be on the top level because the roof receives more sun in summer (than vertical surfaces). The coolest zones were on the ground floor, where the building is adjacent to the earth. In this phase, the effects of the different cool roofs were also tested in winter (as well as summer). Although the gravel provided an almost $1^{\circ} \mathrm{C}$ cooler indoor environment in summer, no significant difference with the other roofs was observed in winter.

It should be noted that these results were based on the computer simulations. To validate parts of the results, an experiment on a scale model and a field measurement were done. The experiment focused on the effect of the different materials (used in the simulations), and the field measurement assessed the simulation software results. Thus, two complementary phases were added to the research:

In phase 2, the effects of the mentioned roofs were tested using a 1/100 scale model of an urban courtyard block. The experiment confirmed that cool roofs provide cooler indoor environments. The added value of this study was to show that an irrigated cool roof (covered with gravel or grass) has a much higher cooling effect than the dry equivalent.

In phase 3, the accuracy of DesignBuilder as the simulation program used in this paper was tested through a one-month (May 2014) field measurement of an actual courtyard house. The simulation and measurement results of four rooms inside this house were compared. The average root mean square deviation of all rooms combined was $0.91^{\circ} \mathrm{C}$. The air temperature of the courtyard was also compared to the air temperature at a nearby airport. On average, the courtyard had $\mathrm{a}+1.5^{\circ} \mathrm{C}$ higher air temperature than the airport.

Returning back to the aims of this paper, different parameters for designing a courtyard (such as orientations and roof types) were discussed. The findings help to design courtyard buildings more efficiently for the warmer future of the Netherlands. Results on the effect of the different cool roofs could be used for greening and retrofitting existing buildings and making them climate proof. 


\section{References}

[1] IPCC, Climate Change 2007, in: S. Solomon, D. Qin, M. Manning, Z. Chen, M. Marquis, K.B. Averyt, M. Tignor, M. H.L. (Eds.) The physical science basis. Contribution of the working group I to the fourth assessment report of the intergovernmental panel on climate change, Cambridge, 2007.

[2] KNMI, KNMI'14 climate scenarios for the Netherlands; A guide for professionals in climate adaptation, in, KNMI, De Bilt, The Netherlands, 2014.

[3] A. Okeil, A holistic approach to energy efficient building forms, Energy and Buildings, 42 (9) (2010) 1437-1444.

[4] C. Ratti, D. Raydan, K. Steemers, Building form and environmental performance: archetypes, analysis and an arid climate, Energy and Buildings, 35 (1) (2003) 49-59.

[5] L. Martin, L. March, Urban Space and Structures, Cambridge University Press, UK, 1972.

[6] M. Taleghani, M. Tenpierik, A. van den Dobbelsteen, R. de Dear, Energy use impact of and thermal comfort in different urban block types in the Netherlands, Energy and Buildings, 67 (0) (2013) 166175.

[7] A.H. Rosenfeld, H. Akbari, S. Bretz, B.L. Fishman, D.M. Kurn, D. Sailor, H. Taha, Mitigation of urban heat islands: materials, utility programs, updates, Energy and Buildings, 22 (3) (1995) 255-265.

[8] M. Taleghani, M. Tenpierik, A. Dobbelsteen, D. Sailor, Heat mitigation strategies in winter and summer: field measurements in temperate climates, Building and Environment, ((accepted)).

[9] H. Akbari, U.S.E.P.A.C.C. Division, L.B. Laboratory, U.S.D.o. Energy, Cooling our communities: a guidebook on tree planting and light-colored surfacing, U.S. Environmental Protection Agency, Office of Policy Analysis, Climate Change Division, 1992.

[10] H. Akbari, H.D. Matthews, Global cooling updates: Reflective roofs and pavements, Energy and Buildings, 55 (0) (2012) 2-6.

[11] H. Taha, Urban climates and heat islands: albedo, evapotranspiration, and anthropogenic heat, Energy and Buildings, 25 (2) (1997) 99-103.

[12] D.J. Sailor, Risks of summertime extreme thermal conditions in buildings as a result of climate change and exacerbation of urban heat islands, Building and Environment, 78 (0) (2014) 81-88.

[13] H. Akbari, M. Pomerantz, H. Taha, Cool surfaces and shade trees to reduce energy use and improve air quality in urban areas, Solar Energy, 70 (3) (2001) 295-310.

[14] M. Santamouris, Cooling the cities - A review of reflective and green roof mitigation technologies to fight heat island and improve comfort in urban environments, Solar Energy, 103 (0) (2014) 682-703.

[15] J. Kapsomenakis, D. Kolokotsa, T. Nikolaou, M. Santamouris, S.C. Zerefos, Forty years increase of the air ambient temperature in Greece: The impact on buildings, Energy Conversion and Management, 74 (0) (2013) 353-365.

[16] L. Doulos, M. Santamouris, I. Livada, Passive cooling of outdoor urban spaces. The role of materials, Solar Energy, 77 (2) (2004) 231-249.

[17] M.A. Lokoshchenko, Urban 'heat island' in Moscow, Urban Climate, (0).

[18] P.I. Konstantinov, M.I. Varentsov, E.P. Malinina, Modeling of thermal comfort conditions inside the urban boundary layer during Moscow's 2010 summer heat wave (case-study), Urban Climate, (0). [19] C. Rinner, M. Hussain, Toronto's Urban Heat Island-Exploring the Relationship between Land Use and Surface Temperature, Remote Sensing, 3 (6) (2011) 1251-1265.

[20] H. Akbari, S. Konopacki, Energy effects of heat-island reduction strategies in Toronto, Canada, Energy, 29 (2) (2004) 191-210.

[21] S. Thorsson, F. Lindberg, J. Björklund, B. Holmer, D. Rayner, Potential changes in outdoor thermal comfort conditions in Gothenburg, Sweden due to climate change: the influence of urban geometry, International Journal of Climatology, 31 (2) (2011) 324-335.

[22] J. Sproul, M.P. Wan, B.H. Mandel, A.H. Rosenfeld, Economic comparison of white, green, and black flat roofs in the United States, Energy and Buildings, 71 (0) (2014) 20-27.

[23] M. Zhao, J. Srebric, Assessment of green roof performance for sustainable buildings under winter weather conditions, J. Cent. South Univ. Technol., 19 (3) (2012) 639-644. 
[24] K. Liu, J. Minor, Performance evaluation of an extensive green roof, in, National Research Council of Canada, 2005.

[25] M. Taleghani, M. Tenpierik, A. van den Dobbelsteen, Energy performance and thermal comfort of courtyard/atrium dwellings in the Netherlands in the light of climate change, Renewable Energy, 63 (0) (2014) 486-497.

[26] D.J. Sailor, A green roof model for building energy simulation programs, Energy and Buildings, 40 (8) (2008) 1466-1478.

[27] ASHRAE, ASHRAE Standard 55-2010 in: Thermal Environmental Conditions for Human Occupancy, ASHRAE Atlanta, GA, 2010.

[28] M. Taleghani, M. Tenpierik, S. Kurvers, A. van den Dobbelsteen, A review into thermal comfort in buildings, Renewable and Sustainable Energy Reviews, 26 (0) (2013) 201-215.

[29] M. Kottek, J. Grieser, C. Beck, B. Rudolf, F. Rubel, World Map of the Köppen-Geiger climate classification updated, Meteorologische Zeitschrift, 15 (3) (2006).

[30] KNMI, in: Climate Change Scenarios 2006 for the Netherlands, KNMI publication: WR-2006-01 2006.

[31] R.M. Lazzarin, F. Castellotti, F. Busato, Experimental measurements and numerical modelling of a green roof, Energy and Buildings, 37 (12) (2005) 1260-1267.

[32] E.G. McPherson, L.P. Herrington, G.M. Heisler, Impacts of vegetation on residential heating and cooling, Energy and Buildings, 12 (1) (1988) 41-51.

[33] M. Santamouris, Environmental Design of Urban Buildings: An Integrated Approach, Taylor \& Francis, 2012. 